\title{
Factors affecting the quality of manufacturer - distributor relationship in the plastic industry in Vietnam
}

\author{
Ho Thanh Phong ${ }^{1}$, Tran Van Khoat ${ }^{2 *}$ \\ ${ }^{1}$ HongBang International University, Vietnam \\ ${ }^{2}$ University of Economics Ho Chi Minh City, Vietnam \\ *Corresponding author: vkhoat@gmail.com
}

\begin{tabular}{ll}
\hline \multicolumn{1}{c}{ ARTICLE INFO } & \multicolumn{1}{c}{ ABSTRACT } \\
$\begin{array}{l}\text { DOI:10.46223/HCMCOUJS. } \\
\text { econ.en.10.2.583.2020 }\end{array}$ & $\begin{array}{l}\text { This study explores and examines the factors that affect } \\
\text { the composition of the quality relationship between } \\
\text { manufacturers and distributors in the context of the plastic } \\
\text { industry in Vietnam. Qualitative research worked on single and } \\
\text { group discussions with } 23 \text { manufacturers and distributors in the } \\
\text { plastics industry. Quantitative research directly interviewed }\end{array}$ \\
$\begin{array}{l}\text { Received: July } 21^{\text {st }}, 2020 \\
\text { Revised: August } 11^{\text {th }}, 2020\end{array}$ & $\begin{array}{l}\text { 560 plastic product distributors in Ho Chi Minh City area and } \\
\text { Southern provinces. The results of the study determined the } \\
\text { Accepted: August } 20^{\text {th }}, 2020\end{array}$ \\
$\begin{array}{l}\text { Keywords: } \\
\text { of trust, commitment and satisfaction; six factors of product } \\
\text { Relationship Quality, manufacturer } \\
\text { - distributor relationship, plastic } \\
\text { industry, Vietnam }\end{array}$ & $\begin{array}{l}\text { quality, delivery quality, market information, communication, } \\
\text { personal interaction, and visits affect the quality of the } \\
\text { relationship between manufacturer and distributor. }\end{array}$ \\
\hline
\end{tabular}

\section{Introduction}

In the competitive market, the success of businesses is partly dependent on other businesses, and the quality of relationships is an important factor to improve competitive advantage (Anderson \& Narus, 1990). Relationship Quality (RQ) is considered a structure made up of many supporting and complementing components (Dwyer, Schurr, \& Oh, 1987). In recent years, there have been many studies on the factors affecting RQ (Aurier \& Séré de Lanauze, 2011; Leonidou, Barnes, \& Talias, 2006; Loureiro \& Cunha, 2017; Smith, 1998; Velez, Sanchez, Florez, $\&$ Alvarez-Dardet, 2015). However, those pieces of research have not shown common consent on the factors affecting RQ (Athanasopoulou, 2008, 2009; Naoui \& Zaiem, 2010; Woo \& Ennew, 2004). According to Athanasopoulou (2009, p. 583), different research contexts would give different results on factors affecting RQ. Besides, most of the previous studies examined the factors affecting RQ in the relationship between buyers and sellers in general, B2B relations, or other relationships. Table 1 shows, among 64 documents on RQ summarized by Athanasopoulou (2009) from 1987 - 2007, there were 14 studies focused on factors affecting RQ. In it, there were only two studies on the relationship between the Car Manufacturer and their dealers (Dwyer et al., 1987; Kumar, Scheer, \& Steenkamp, 1995). Of the 78 RQ studies summarized by the author from 2008 - 2017, 15 studies focused on the factors affecting RQ. In it, there was only one study on the relationship between the Portuguese Wine Manufacturer and Chinese Distributor (Loureiro \& Cunha, 2017). Thus, very few studies consider RQ in the specific relationship between Manufacturer and Distributor. 


\section{Table 1}

Summary of studies on factors affecting the composition of Relationship Quality

\begin{tabular}{|c|c|c|}
\hline No & Author & Background of research \\
\hline $\mathbf{A}$ & $\begin{array}{l}\text { The studies compiled by } \\
\text { Athanasopoulou (2009) }\end{array}$ & \\
\hline 1 & Dwyer et al. (1987) & $\begin{array}{l}\text { The relationship between the car manufacturer and their } \\
\text { dealers in the United States }\end{array}$ \\
\hline 2 & $\begin{array}{l}\text { Lagace, Dahlstrom, and } \\
\text { Gassenheimer (1991) }\end{array}$ & $\begin{array}{l}\text { The relationship between doctors and pharmaceutical } \\
\text { salespeople in the United States }\end{array}$ \\
\hline 3 & $\begin{array}{c}\text { Johnson, Sakano, Cote, and Onzo } \\
\text { (1993) }\end{array}$ & $\begin{array}{l}\text { Relationship between Japanese importer and US } \\
\text { manufacturer }\end{array}$ \\
\hline 4 & Wray, Palmer, and Bejou (1994) & $\begin{array}{l}\text { The relationship between financial intermediaries and } \\
\text { financial service consumers in the United States }\end{array}$ \\
\hline 5 & Kumar et al. (1995) & $\begin{array}{l}\text { The relationship between the car manufacturer and their } \\
\text { dealers in the United States and the Netherlands }\end{array}$ \\
\hline 6 & Bejou, Wray, and Ingram (1996) & $\begin{array}{l}\text { The relationship between salespeople and customers in } \\
\text { financial services in the United States }\end{array}$ \\
\hline 7 & Smith (1998) & $\begin{array}{l}\text { Relationship between purchasing experts and sales } \\
\text { representatives in Canada }\end{array}$ \\
\hline 8 & $\begin{array}{l}\text { Hopkinson and Hogarth-Scott } \\
\text { (1999) }\end{array}$ & The relationship between the franchise parties \\
\hline 9 & $\begin{array}{l}\text { Baker, Simpson and Siguaw } \\
\text { (1999) }\end{array}$ & $\begin{array}{l}\text { The relationship between suppliers and their agents in } \\
\text { the US }\end{array}$ \\
\hline 10 & $\begin{array}{l}\text { Hibbard, Kumar, and Stern } \\
\text { (2001) }\end{array}$ & $\begin{array}{l}\text { The relationship between suppliers and their agents in } \\
\text { the US }\end{array}$ \\
\hline 11 & $\begin{array}{l}\text { Walter, Muller, Helfert, and } \\
\text { Ritter (2003) }\end{array}$ & $\begin{array}{l}\text { The relationship between suppliers and professional } \\
\text { buyers in various industries in Germany }\end{array}$ \\
\hline 12 & $\begin{array}{l}\text { Van Bruggen, Kacker, and } \\
\text { Nieuwlaat (2005) }\end{array}$ & $\begin{array}{l}\text { Relationship between B2B professional painters and } \\
\text { paint distributors in Belgium and the Netherlands }\end{array}$ \\
\hline 13 & Leonidou et al. (2006) & The relationship between US exporters and importers \\
\hline 14 & Ndubisi (2006) & $\begin{array}{l}\text { Relationship between banks and retail customers in } \\
\text { Malaysia }\end{array}$ \\
\hline $\mathbf{B}$ & $\begin{array}{l}\text { The research synthesized by } \\
\text { the author }\end{array}$ & \\
\hline 1 & $\begin{array}{c}\text { Skarmeas, Katsikeas, } \\
\text { Spyropoulou, and Sangari (2008) }\end{array}$ & $\begin{array}{l}\text { The relationship between the distributor of imports and } \\
\text { foreign suppliers in England }\end{array}$ \\
\hline 2 & Clark, Adjei, and Yancey (2009) & $\begin{array}{l}\text { The relationship between the Restaurant and their } \\
\text { customers in the Southeast United States }\end{array}$ \\
\hline
\end{tabular}




\begin{tabular}{|c|c|c|}
\hline No & Author & Background of research \\
\hline 3 & $\begin{array}{l}\text { T. T. M. Nguyen and T. D. } \\
\text { Nguyen (2010) }\end{array}$ & $\begin{array}{l}\text { Relationship between Vietnamese exporters and } \\
\text { foreign importers }\end{array}$ \\
\hline 4 & $\begin{array}{l}\text { Aurier and Séré de Lanauze } \\
\qquad(2011)\end{array}$ & $\begin{array}{l}\text { The relationship between customers and the brand } \\
\text { image of the manufacturer in Supermarkets in France }\end{array}$ \\
\hline 5 & $\begin{array}{l}\text { T. D. Nguyen and T. T. M. } \\
\text { Nguyen (2011) }\end{array}$ & $\begin{array}{l}\text { Quality brand relationship of some consumer products } \\
\text { in Vietnam }\end{array}$ \\
\hline 6 & Shpetim (2012) & $\begin{array}{l}\text { The relationship between partners in the supply chain: } \\
\text { food, construction, tourism, hospital, shoe leather ... in } \\
\text { Albania }\end{array}$ \\
\hline 7 & $\begin{array}{l}\text { Ebrahimi, Haghighinasab, } \\
\text { Sattari, and Roghanian (2013) }\end{array}$ & $\begin{array}{l}\text { Relationship between partners in food distribution } \\
\text { channels in Iranian }\end{array}$ \\
\hline 8 & $\begin{array}{l}\text { Moliner, Moliner, and Sanchez- } \\
\text { Garcia (2013) }\end{array}$ & B2B relationship in Spain \\
\hline 9 & $\begin{array}{l}\text { Athanasopoulou, } \\
\text { Kalogeropoulou, and Douvis } \\
\text { (2013) }\end{array}$ & $\begin{array}{l}\text { Relationship between customers and sports service } \\
\text { providers in Greece }\end{array}$ \\
\hline 10 & $\begin{array}{l}\text { Pepur, Mihanovic, and Pepur } \\
\text { (2013) }\end{array}$ & Relationship in financial services of hotels in Croatia \\
\hline 11 & $\begin{array}{l}\text { Madupalli, Pannirselvam, and } \\
\text { Williams (2014) }\end{array}$ & $\begin{array}{l}\text { Relationship between cultural suppliers in the United } \\
\text { States }\end{array}$ \\
\hline 12 & $\begin{array}{l}\text { T. T. M. Nguyen and T. D. } \\
\text { Nguyen (2014) }\end{array}$ & $\begin{array}{l}\text { Relationship between Vietnamese exporters and } \\
\text { foreign importers }\end{array}$ \\
\hline 13 & Velez et al. (2015) & $\begin{array}{l}\text { Relationship between exporting small and medium } \\
\text { enterprises and foreign intermediaries in Spain }\end{array}$ \\
\hline 14 & $\begin{array}{l}\text { Japutra, Keni, and Nguyen } \\
\qquad(2015)\end{array}$ & $\begin{array}{l}\text { The relationship between consumers and the brand logo } \\
\text { in Indonesia }\end{array}$ \\
\hline 15 & Loureiro and Cunha (2017) & $\begin{array}{l}\text { Relationship between Portuguese Wine Manufacturer } \\
\text { and Chinese Distributor }\end{array}$ \\
\hline
\end{tabular}

Source: Author's synthesis

In the practical context, plastic industry is a strategic industry in Vietnam. The annual growth rate in the 2013 - 2017 period is from 16\% - 18\%. According to the statistics of Vietnam Plastics Association, in 2018, the country has more than 2,000 enterprises producing and trading plastic products, of which more than $80 \%$ are small and medium enterprises. These production and distribution units are less interested in the quality of relationships, so they often face difficulties in product consumption, market information, etc. According to T. D. Nguyen and T. T. M. Nguyen (2011, p. 319), Vietnamese manufacturers need to find ways to establish quality relationships with distributors. 
In addition, in Vietnam, there has no document studying the factors affecting RQ between manufacturers and distributors in the plastic industry. To fill the gap, this study aims to discover and measure the component scale of RQ and the factors affecting the composition of RQ between producers and distributors in the context of the plastic industry in a transition economy like Vietnam. The research results revealed that three components of RQ are trust, commitment, and satisfaction; six factors affect the composition of RQ: product quality, delivery quality, market information, communication, personal interaction, and visits. The results of this study added to the theory of RQ between manufacturer - distributor in the context of transition economy; discovering the visitation scale, developing the scale of market information from the scale of market information system of Sabherwal and Chan (2001); three scales of product quality, quality of delivery, and personal interaction are derived from the relationship value which is now accepted in RQ research, these factors affect to the composition of RQ between manufacturer - distributor, contributing to the scale system of factors affecting RQ components. Also, practically, the results of the study help manufacturers identify the most important factors affecting RQ with distributors. Thus, propose strategies and measures to maintain and develop the relationship between manufacturers - distributors.

The next part of this study presents theories and hypotheses, research methodology, research results, discussions, conclusions and implications, limitations, and directions for further research.

\section{Theoretical and hypothetical basis}

\subsection{Relationship quality}

Quality Relationship (RQ) is derived from relationship marketing. According to Berry (1995, p. 236), relationship marketing is the attraction, maintenance, and organization of activities to enhance relationships with customers. Crosby, Evans, and Cowless (1990) argued that seller experience and sales behavior were important to create and maintain long-term business relationships with customers. The purpose of relationship marketing is to create, manage relationships with customers and other partners so that the parties were in a relationship that satisfies both purpose and mutual benefit (Grönroos, Storbacka, \& Strandvik, 1994). RQ is an extension of relationship marketing (Bojei \& Alwie, 2010), referring to customers 'perceptions of relationships, meeting customers' goals, and wants (Jarvelin \& Lehtinen, 1996).

Recently, there have been many studies on the concept of RQ. According to Dwyer et al. (1987), RQ is an overall structure consisting of several important relationship results reflecting the overall nature of the exchange relationship. RQ includes conflict, trust, commitment, investment willingness, and expectation of continuity (Kumar et al., 1995). Skarmeas et al. (2008, p. 23) argued that RQ is a high-level structure of trust, commitment, and satisfaction. RQ includes satisfaction and trust (Huang, Davison, \& Liu, 2014, p. 954). According to Izogo, Reza, Ogba, and Oraedu (2017), RQ is a structure that included trust and satisfaction. Thus, the above studies have not had a consensus on the composition of relationship quality (Athanasopoulou, 2009; Bove \& Johnson, 2001; Naude \& Buttle, 2000; Rauyruen \& Miller, 2007).

\subsection{Composition of relationship quality}

According to Naoui and Zaiem (2010, p. 142), the components of RQ could be divided into three groups: (1) Group of behavioral intention: sales orientation, communication, and opportunism ...; (2) Group of relationships: satisfaction, commitment, and trust; and (3) Group of results of the relationship: economic benefits, customer benefits, etc. In which, the relationship group, including trust, commitment, and satisfaction was said to be the outstanding factors RQ 
(Crosby et al., 1990; Kumar et al., 1995; Moliner et al., 2013; Skarmeas et al., 2008). This study performed a qualitative method, through bilateral discussion (sample $n=15$ ) and group discussion (sample $\mathrm{n}=8$ ) with managers of manufacturing and distribution companies in the plastic industry in HCMC. Ho Chi Minh City discovered that belief, commitment, and satisfaction are the three components of RQ.

Trust: A willingness to rely on an exchange partner that is trusted (Moorman, Zaltman, \& Deshpande, 1993; Skarmeas et al., 2008); is the prestige, credibility, and benevolence of exchange partners (Doney \& Cannon, 1997; Lindskold, 1978). In business relationships, customers try to reduce risk by choosing a provider that is deemed reliable (Ulaga \& Eggert, 2006).

Commitment: is a long-term desire to maintain a relationship value (Moorman et al., 1993), which is the foundation of relationship marketing (Ulaga \& Eggert, 2006). Morgan and Hunt (1994, p. 23) argued that commitment is the key to achieve valuable outcomes for relationships. A high level of commitment will help stabilize relationships (Ulaga \& Eggert, 2006).

Satisfaction: According to Geyskens, Steenkamp, and Kumar (1999), satisfaction refers to the social as well as economic aspects of the exchange, which is an essential element of successful relationships between companies (Jap \& Ganesan, 2000; Skarmeas et al., 2008). Building satisfaction is essential, consistent with many studies in the business relationship between shoppers and suppliers (Geyskens et al., 1999; Ulaga \& Eggert, 2006).

\subsection{Factors affecting the quality of relationships}

Factors affecting RQ have been mentioned by many studies (Athanasopoulou, 2008, 2009; Naoui \& Zaiem, 2010). However, studies do not have a general agreement on the factors affecting RQ (Naoui \& Zaiem, 2010). According to Athanasopoulou (2009, p. 600), the factors affecting RQ are classified into four main groups: (1) Group of relationships (buyers and sellers); (2) Group of relationship attributes; (3) Group of supply characteristics and (4) Group of environmental factors. This study selected several factors to perform the qualitative method, through bilateral discussion and group discussion with 23 managers in the plastic industry in HCMC. As a result, six factors have been identified affecting RQ: (i) Product quality; (ii) Delivery quality; (iii) Market information; (iv) Communication; (v) Personal interaction; and (vi) Visit. To formulate the hypotheses about the factors affecting RQ between manufacturer and distributor, the next section presents the effect of factors on the components of RQ.

Product quality affects the components of RQ: According to Ulaga (2003, p. 683), product quality is the degree to which the supplier's product meets the customer's technical standard requirements. In the relationship between distributor - manufacturer, distributor keeps a relationship with manufacturer to always be provided with high quality and reliable products (T. D. Nguyen \& T. T. M. Nguyen, 2011). According to Ulaga and Eggert (2006, p. 322), the relationship value is a precursor to RQ. However, very few documents considering product quality affect RQ. Because product quality is an indispensable element of customer value (Ulaga \& Eggert, 2006), and when suppliers sell high-quality products, they will positively impact RQ (Chen, Su, \& Ro, 2017, p. 247). In addition, in qualitative research, experts argue that when a manufacturer gives a distributor good quality products, it will create a trust for distributor, proving that the commitments between the two parties have been made, and when a distributor can sell a product, the manufacturer feels that the distributor has performed well and they are satisfied with each other. Therefore, based on research by T. D. Nguyen and T. T. M. Nguyen (2011), our study examined how product quality impacts on three components (trust, commitment, and satisfaction) of the quality relationship between manufacturer and distributor, with three hypotheses as follows: 
Hla: Product quality has a positive impact on trust between a manufacturer and a distributor

H1b: Product quality has a positive impact on the commitment between manufacturer and distributor

H1c: Product quality has a positive impact on satisfaction between a manufacturer and a distributor

Delivery quality affects components of RQ: Delivery is the process of transporting goods from source location to predetermined destination (Nishio \& Kishino, 1999), and is a source of strategic measures in the supply chain (Forslund, Jonsson, \& Mattsson, 2009). Quality of delivery is a factor that increases the value of the relationship between manufacturer and distributor (T. D. Nguyen \& T. T. M. Nguyen, 2011, p. 320). On the other hand, in the bilateral and group discussions with experts in qualitative research, they said that when the manufacturer ensures fully, timely and accurate delivery of products and goods, this will gain trust to the distributor, so the manufacturer has made commitments to the distributor on delivery, and then they are satisfied with each other. However, very little research considers the delivery factor affecting the quality of relationships. Based on documents by T. D. Nguyen and T. T. M. Nguyen (2011), this study examined the impact of delivery quality on the three components of the relationship quality between manufacturer and distributor, with the following hypotheses:

H2a: Delivery quality has a positive impact on trust between a manufacturer and a distributor

H2b: Delivery quality has a positive impact on the commitment between a manufacturer and a distributor

H2c: Delivery quality has a positive impact on satisfaction between a manufacturer and a distributor

Market information affects the components of RQ: Harmancioglu, Grinstein, and Goldman (2010) argued that market information is the external data related to the present and future of a business. In the manufacturer - distributor relationship, appropriate information from the manufacturer will help the distributor understand the production plan, changes in product technology (T. D. Nguyen and T. T. M. Nguyen, 2011). Because market information is central to decision making (Collins \& Clark, 2003) and plays an important role in business relationships (Cannon \& Homburg, 2001). And in qualitative research, the experts explained that, due to the characteristics of the plastic industry, the manufacturer does market research and provides information for the distributor. Therefore, when the manufacturer fully and timely provides market information for the distributor, it will create confidence for the distributor, the manufacturer committed to provide market information, and so the distributor will be satisfied with the manufacturer. Based on research by Sabherwal and Chan (2001), our study examined the impact of market information on the three components of the relationship quality between manufacturer and distributor, with the following theory:

H3a: Market information has a positive impact on trust between a manufacturer and a distributor

H3b: Market information has a positive impact on the commitment between a manufacturer and a distributor

H3c: Market information has a positive impact on satisfaction between a manufacturer and a distributor 
Communication affects the components of RQ: Communication is to provide customers with complete information as well as listening to them when they need to communicate (Parasuraman, Zeithaml, \& Berry, 1985; Tohidinia \& Haghighi, 2011). Communication between the manufacturer and the distributor is the glue to keep their relationship (Song \& Zhao, 2004). If ineffective communication will significantly affect commitment, satisfaction, and ultimately affect RQ (Bojei \& Alwie, 2010, p. 88). Besides, experts in qualitative research argue that when the manufacturer communicates well with the distributor about ordering, delivery, and payment, the two parties will understand each other, thereby creating a trust for the distributor. Through reviewing the literature, very little research has been done on the communication that affects the quality of the relationship between manufacturer and distributor. Based on two studies (Rodríguezdel-Bosque, Agudo, \& Gutierrez, 2006; Tohidinia \& Haghighi, 2011), we study communication that affects three components of the manufacturer relationship quality - distributor, with the following assumptions:

H4a: Communication has a positive impact on trust between a manufacturer and a distributor

H4b: Communication has a positive impact on the commitment between a manufacturer and a distributor

H4c: Communication has a positive impact on satisfaction between a manufacturer and a distributor

Personal interaction affects the components of RQ: Personal interaction is an important element of interaction between organizations (Mainela \& Ulkuniemi, 2013). In the relationship between manufacturer and distributor, personal interaction involves an individual-level interaction between manufacturer and distributor (T. D. Nguyen \& T. T. M. Nguyen, 2011; Ulaga, 2003). Improving personal interaction between manufacturer and distributor will benefit both parties through better communication and better performance (Cater \& Cater, 2010). Because individuals play an important role in any business relationship (Ulaga, 2003). On the other hand, in qualitative research, experts say, enhancing personal interaction between manufacturer and distributor will help both parties have more opportunities to communicate, communicate better, and understand each other's goals. Since then, there has been an increase in trust and satisfaction due to the commitment of exchange levels between the two parties. However, very few documents consider personal interaction affecting the quality of relationships. Based on research by T. D. Nguyen and T. T. M. Nguyen (2011), this study examined how the individual interaction factor affects three components of the quality of relationship manufacturer - distributor, with the following assumptions:

H5a: Personal interaction has a positive impact on trust between a manufacturer and a distributor

H5b: Personal interaction has a positive impact on the commitment between a manufacturer and a distributor

H5c: Personal interaction has a positive impact on satisfaction between a manufacturer and a distributor

Visiting affects the components of RQ: According to John and Christopher (1999, p. 1287), suppliers visit their customers to consider their business ability and financial capacity. Some studies have mentioned the need to visit customers and make plans and frequencies to visit customers (Baldoquin de la Pena, Escalera Farinas, \& Linfati, 2014; Narus \& Anderson, 1987). In 
the relationship between manufacturer and distributor, manufacturer visits distributor to make agreements on sales policies and conduct orders (Narus \& Anderson, 1987, p. 37). The frequency with which a manufacturer visits customers in business relationships reflects the intensity of information gathering and that customers will have better sales policies (John \& Christopher, 1999, p. 1288). The above documents only mention the need to visit customers, consider planning, visit schedules. Very few research papers on visiting scales affect RQ. Because visits are an equally important element in business strategies and strategies of businesses (Baldoquin et al., 2014, p. $333)$.

Moreover, experts in qualitative research explained that the more manufacturer visits distributor (or vice versa), the more they understand each other. Distributor feels that the publisher is interested in them so they trust the manufacturer, the requirements of the distributor for the publisher are satisfied, so they are satisfied with the manufacturer, from which the commitments between both parties are possible. Therefore, our study examined how the visitation factor affects the three components of the quality relationship between manufacturer and distributor, with the following assumptions:

H6a: Visiting has a positive impact on trust between a manufacturer and a distributor

H6b: Visiting has a positive impact on the commitment between a manufacturer and a distributor

H6c: Visiting has a positive impact on satisfaction between a manufacturer and a distributor

\subsection{Research models}

Based on the above theory and 18 hypotheses, the theoretical model is proposed in Figure 1.

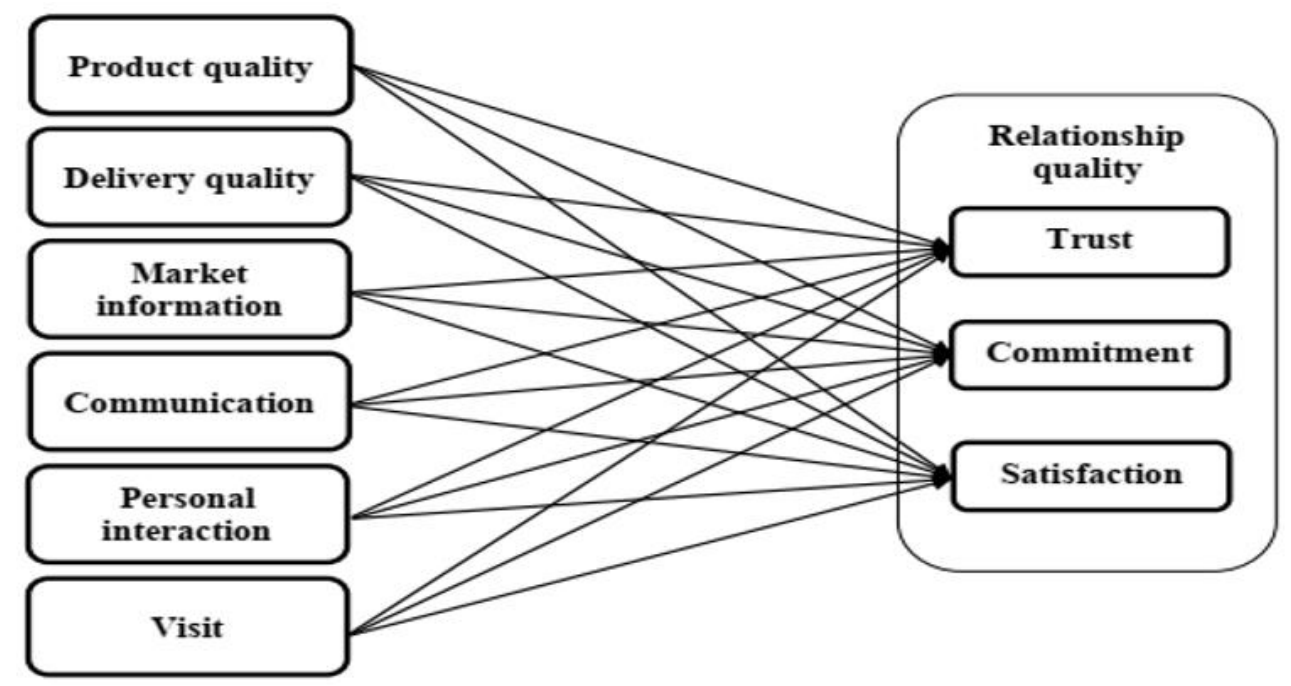

Figure 1. Theoretical model

\section{Research methods}

\subsection{Observation scale and variable}

The observed variable of the scales in the questionnaire of this study is based on the relevant studies presented in Table 2. Through qualitative research, the experts have commented and modified the sentence to suit the context in Vietnam. After editing, the preliminary questionnaire has 9 scales and 36 observed variables. The seven-point Likert scale is used to assess 
the level of the consent of questions, with 1 (completely disagree), ... to 7 (totally agree). This study examined distributors (or from the buyer's point of view). Because most of the previous research on RQ surveyed from the perspective of buyers. On the other hand, according to Ural (2009), the evaluation of quality from the two sides' point of view may give similar results. Also, in the plastic industry in Vietnam, the number of distributors is higher than that of manufacturers, the mass survey will result in more generalized results.

Table 2

Observation scale and variable

\begin{tabular}{|c|c|c|c|}
\hline Observation scale & Encoded & $\begin{array}{l}\text { Number of } \\
\text { variables }\end{array}$ & Related research \\
\hline Trust & $\operatorname{Tr}$ & 5 & \multirow{3}{*}{$\begin{array}{l}\text { Ulaga and Eggert (2006), Skarmeas et al. } \\
(2008)\end{array}$} \\
\hline Commitment & Co & 4 & \\
\hline Satisfaction & $\mathrm{Sa}$ & 4 & \\
\hline Product quality & $\mathrm{Pq}$ & 3 & \multirow{2}{*}{ T. D. Nguyen and T. T. M. Nguyen (2011) } \\
\hline Delivery quality & $\mathrm{Dq}$ & 3 & \\
\hline Market information & $\mathrm{Mi}$ & 4 & Sabherwal and Chan (2001) \\
\hline Communication & Com & 5 & $\begin{array}{l}\text { Rodríguez-del-Bosque et al. (2006), } \\
\text { Tohidinia and Haghighi (2011) }\end{array}$ \\
\hline Personal interaction & $\mathrm{Pi}$ & 4 & T. D. Nguyen and T. T. M. Nguyen (2011) \\
\hline Visit & Vi & 4 & Explores in qualitative research \\
\hline
\end{tabular}

Source: Author's synthesis

\subsection{Data and analytical methods}

Qualitative research was through hands-on discussion and group discussion with 23 managers of plastic product manufacturing and distribution enterprises in Ho Chi Minh City to explore scales, observed variables on ingredients and Factors affecting RQ.

The preliminary quantitative method of surveying distributor plastic products in HCMC area was using non-probability sampling, using the convenience sampling method combined with judgment sampling to select patterns. The total number of survey samples was 170 . Use 170 questionnaires to interview. The number of questionnaires to be returned is 148 . The number of satisfactory questionnaires is 136 . Use Cronbach alpha and exploratory factor analysis to evaluate the reliability and scale values.

The quantitative method officially interviewed distributors plastic products in Ho Chi Minh City area, Western provinces, and some Southeast provinces. The list of distributors is provided by Vietnam Plastics Association and some major Manufacturer. However, data is not complete, it can't choose the sample under probability sampling. So quantitative research gets non-probability sampling using quota sampling, divide level under the group to choose a sample. According to Sarstedt, Bengart, Shaltoni, and Lehmann, (2017, p. 2), getting probability sampling is the main method in many decades, however, due to the advantages of cost and convenience, non-probability sampling always finds a position in academic research. Theoretically, non-probability sampling can achieve the same results as probability samples (Sarstedt et al., 2017, p. 3). Besides, some 
researchers believed that the quota sampling method can make results comparable to probability sampling results (Brick, 2011; Cumming, 1990; Yang \& Banamah, 2014). The total number of selected samples is 700 . Use 700 questionnaires to interview. The number of questionnaires to be returned is 616. The number of questionnaires is 560. Cronbach alpha and EFA analysis continue to be used. Scale test by CFA analysis. Check the appropriateness of the model and research hypothesis with SEM model.

\section{Research results}

\subsection{Evaluate the scale}

Preliminary assessment: Results of reliability assessment of scale with Cronbach alpha coefficient. Scale: Trust (Tr), Commitment (Co), Satisfaction (Sa), Product quality (Pq), Delivery quality (Dq), Personal interaction (Pi), Marketing information (Mi), Visit (Vi) all ensure the necessary reliability, with the coefficient $\alpha>.60$. The correlation coefficient of the total observed variables is $>.30$. For the Communication scale $(\mathrm{Com})$, the variable Com 2 has the total variable correlation coefficient of $.242<.30$ so this variable is eliminated.

Results of evaluation of scale values by EFA analysis, concepts in group 1 (elements of RQ) have 3 factors extracted at Eigenvalue $=2.361>1$ and total variance extracted is $67.583 \%>$ $60 \%$. The concepts in group 2 (factors affecting RQ) have 6 factors extracted at Eigenvalue $=$ $1,725>1$ and the total variance extracted is $63.378 \%>60 \%$. The factor weight of the observed variables of scales in groups 1 and 2 is > .50. The Com 2 variable has a factor weight of $.381<.50$ so this variable is eliminated. Also, the observed variables of the two groups had a factor weighting difference between the factor weight of that variable and other factors $>.30$. Therefore, the scale values of concepts in groups 1 and 2 are satisfactory.

After the preliminary assessment, there is one observed variable Com2 removed. Therefore, the remaining 35 observed variables were used in official quantitative research.

Official assessment: Results of assessing the reliability of 9 scales ( $\mathrm{Tr}, \mathrm{Co}, \mathrm{Sa}, \mathrm{Pq}, \mathrm{Dq}, \mathrm{Mi}, \mathrm{Com}$, $\mathrm{Pi}, \mathrm{Vi}$ ) are equal to Cronbach alpha coefficients. The scales in a formal research ensure reliability, with coefficients $\alpha>.60$ and greater than the coefficient $\alpha$ in the preliminary study. The correlation coefficient of the total observed variables is $>.30$. Thus, these scales achieve reliability.

In the preliminary study, due to the small sample size $(n=136)$, it is recommended to use the scale value scale for each scale group and according to the perpendicular rotation (Varimax). In the official study, larger sample sizes $(n=560)$ should use EFA to evaluate scales at the same time and use Promax rotation. Because Promax reflects a more accurate data structure than Varimax (Gerbing \& Anderson, 1988), and is a popular method for running SEM models (Hair, Black, Babin, \& Anderson, 2010).

EFA results of the scales in the official study have 9 factors extracted at Eigenvalue $=1,027$ $>1$ and the total variance extracted (TVE) is $64.391 \%>60 \%$. This indicates that scales explain concepts well. The factor weight of the variables in the 9 scales is $>.50$. Particularly observed variable $\operatorname{Tr} 5$ has a factor weight of $.448<.50$; Mi1 variable has a factor weight of .486 <.50; Com5 variable has a factor weight of $.478<.50$. So 3 variables: Tr5, Mi1, and Com5 are excluded. The observed variables have a factor weight difference between the factor weight of that variable and other factors $>.30$. Therefore, the scale value of these concepts is satisfactory.

The official evaluation results have removed 3 unobserved observations in the scales. Specifically, the variables: Tr5, Mi1, and Com5. According to Table 3, 32 observed variables are in satisfactory scales and are included in the test in the following methods. 
Table 3

Official assessment results - reliability and value of the scale

\begin{tabular}{|c|c|c|c|}
\hline Encoded & Items & $\alpha$ & $\lambda$ \\
\hline & Trust, $\alpha=.873$ & & \\
\hline $\operatorname{Tr} 1$ & Manufacturers always keep their promises. & .846 & .627 \\
\hline $\operatorname{Tr} 2$ & Manufacturers always care about our business situation. & .843 & .793 \\
\hline $\operatorname{Tr} 3$ & $\begin{array}{l}\text { Manufacturers always consider our benefit as well as their } \\
\text { benefit. }\end{array}$ & .840 & 937 \\
\hline \multirow[t]{2}{*}{$\operatorname{Tr} 4$} & We believe that manufacturers always think of our benefit. & .848 & .691 \\
\hline & Commitment, $\alpha=.861$ & & \\
\hline Co1 & We are well-conduced commitments with the manufacturer. & .841 & .712 \\
\hline $\mathrm{Co} 2$ & $\begin{array}{l}\text { The relationship with manufacturers is really important to our } \\
\text { business. }\end{array}$ & .814 & .852 \\
\hline Co3 & $\begin{array}{l}\text { The relationship with manufacturers helps us to sustain our } \\
\text { business activities in the long term. }\end{array}$ & .806 & .886 \\
\hline \multirow[t]{2}{*}{ Co4 } & $\begin{array}{l}\text { The relationship between us and our manufacturers is } \\
\text { sustainable. }\end{array}$ & .832 & .625 \\
\hline & Satisfaction, $\alpha=.906$ & & \\
\hline Sa1 & $\begin{array}{l}\text { The decision of doing business with our manufacturers is the right } \\
\text { decision. }\end{array}$ & .885 & .791 \\
\hline $\mathrm{Sa} 2$ & We are very satisfied with our manufacturers. & .870 & .918 \\
\hline $\mathrm{Sa} 3$ & $\begin{array}{l}\text { We are very happy with those things that the manufacturers do } \\
\text { for us. }\end{array}$ & .869 & .896 \\
\hline \multirow[t]{2}{*}{$\mathrm{Sa} 4$} & If things begin again, we still choose our manufacturers. & .891 & .734 \\
\hline & Product quality, $\alpha=.841$ & & \\
\hline $\mathrm{Pq} 1$ & Manufacturers always supply a high-quality product to us. & .786 & .814 \\
\hline $\mathrm{Pq} 2$ & Manufacturers always satisfy our quality standards. & .743 & .882 \\
\hline \multirow[t]{2}{*}{$\mathrm{Pq} 3$} & Their products are reliable. & .808 & .690 \\
\hline & Delivery quality, $\alpha=.879$ & & \\
\hline Dq1 & Manufacturers always satisfy our delivery progress. & .832 & .786 \\
\hline Dq2 & We rarely have delivery errors with the manufacturers. & .821 & .833 \\
\hline \multirow[t]{2}{*}{ Dq3 } & $\begin{array}{l}\text { Delivery is always accurate in terms of time, volume, and types } \\
\text { of goods. }\end{array}$ & .832 & .811 \\
\hline & Market information, $\alpha=.837$ & & \\
\hline Mi2 & $\begin{array}{l}\text { Manufacturers help us to introduce our new products/services to } \\
\text { our customers. }\end{array}$ & .760 & .829 \\
\hline Mi3 & Manufacturers help us to track changes in our market share. & .767 & .865 \\
\hline
\end{tabular}




\begin{tabular}{|c|l|c|c|}
\hline Encoded & \multicolumn{1}{|c|}{ Items } & $\boldsymbol{\alpha}$ & $\lambda$ \\
\hline Mi4 & $\begin{array}{l}\text { Manufacturers allow us to quickly adjust the selling price when } \\
\text { market fluctuation happens. }\end{array}$ & .757 & .861 \\
\hline & Communication, $\alpha=.885$ & & \\
\hline Com1 & Manufacturers often contact us. & .855 & .755 \\
\hline Com3 & Manufacturers provide us useful information. & .834 & .917 \\
\hline Com4 & Manufacturers often warn us about changes, which can affect us. & .844 & .780 \\
\hline & Personal interaction, $\alpha=.878$ & & \\
\hline Pi1 & We work with manufacturers easily. & .852 & .751 \\
\hline Pi2 & We interact well with the representative of the manufacturer. & .846 & .826 \\
\hline Pi3 & We solve problems with each other easily. & .824 & .908 \\
\hline Pi4 & We discuss openly with each other. & .850 & .757 \\
\hline & Visit, $\alpha=.828$ & & \\
\hline Vi1 & Manufacturers ask their employees to visit us once every month. & .784 & .729 \\
\hline Vi2 & Manufacturers often ask their employees to visit us. & .740 & .936 \\
\hline Vi3 & Sometimes the manufacturer's director visits us. & .819 & .564 \\
\hline Vi4 & Visiting helps us more tightly corporate. & .785 & .596 \\
\hline
\end{tabular}

Source: Author's synthesis

\subsection{Testing scale}

Figure 2 shows the results of the CFA (standardized) scale analysis of factors affecting three components of $\mathrm{RQ}$, with the following indicators: Chi-square / $\mathrm{df}=2.112<3$; $\mathrm{df}=428 ; \mathrm{P}=$ $.000 ; \mathrm{GFI}=.906 ; \mathrm{TLI}=.951$ and $\mathrm{CFI}=.958$ are all $>.90 ; \mathrm{RMSEA}=.045 \leq .08$. These indicators are satisfactory, so the theoretical model is suitable for market data.

Table 4 shows that the composite reliability (CR) of concepts is $>0.7$, and the average variance extracted (AVE) is both $>0.5$. Consequently, the concepts are satisfactory for aggregate reliability and deduction. The MSV (Maximum Shared Variance) and ASV (Average Shared Variance) indexes of concepts are smaller than the AVE index. Thus, the concepts reach differentiated values. According to Figure 2, the standardized regression coefficients of the observed variables are $>.50$ and all $\mathrm{p}=.000$ values. Therefore, the observed variables are convergent. 


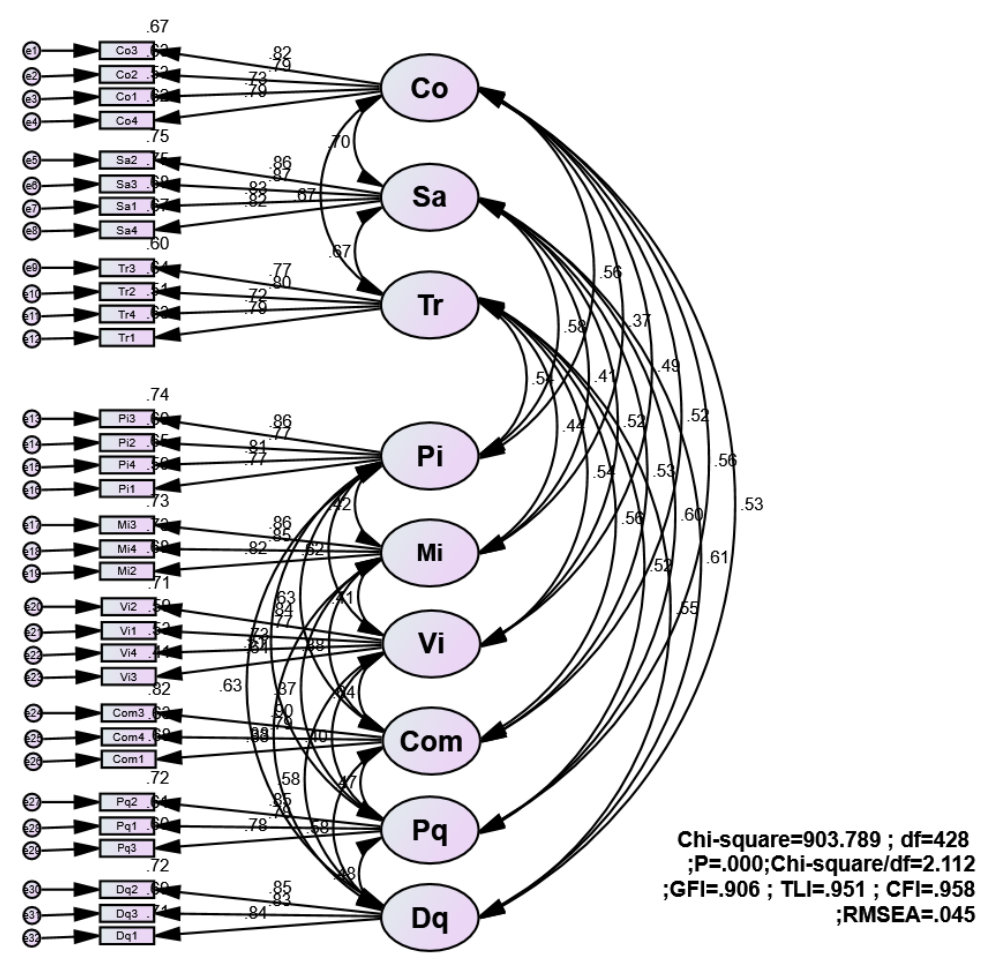

Figure 2. CFA results (standardized)

\section{Table 4}

CFA results of the scales

\begin{tabular}{|l|c|c|c|c|}
\hline \multicolumn{1}{|c|}{ Scales } & CR & AVE & MSV & ASV \\
\hline Commitment & 0.863 & 0.612 & 0.494 & 0.312 \\
\hline Satisfaction & 0.908 & 0.712 & 0.494 & 0.341 \\
\hline Trust & 0.854 & 0.594 & 0.452 & 0.321 \\
\hline Personal interaction & 0.878 & 0.644 & 0.401 & 0.319 \\
\hline Market information & 0.882 & 0.713 & 0.196 & 0.158 \\
\hline Visit & 0.835 & 0.560 & 0.416 & 0.284 \\
\hline Communication & 0.880 & 0.710 & 0.416 & 0.297 \\
\hline Product quality & 0.844 & 0.644 & 0.364 & 0.247 \\
\hline Delivery quality & 0.879 & 0.708 & 0.392 & 0.299 \\
\hline
\end{tabular}

Source: CFA analysis results of the author

\subsection{Results of theoretical and hypothetical testing - discussion}

Verification of theoretical models: Figure 3 presents the results of SEM (standardized) theoretical models of factors affecting three components of RQ, with the indexes: Chi-square / df $=2.389<3 ; \mathrm{df}=431 ; \mathrm{P}=.000 ; \mathrm{GFI}=.894>.80($ Bagozzi \& Yi, 1988); TLI $=.939$ and $\mathrm{CFI}=$ .947 are all $>.90 ;$ RMSEA $=.050 \leq .08$. These indicators are satisfactory, so the theoretical model is compatible with market data. 


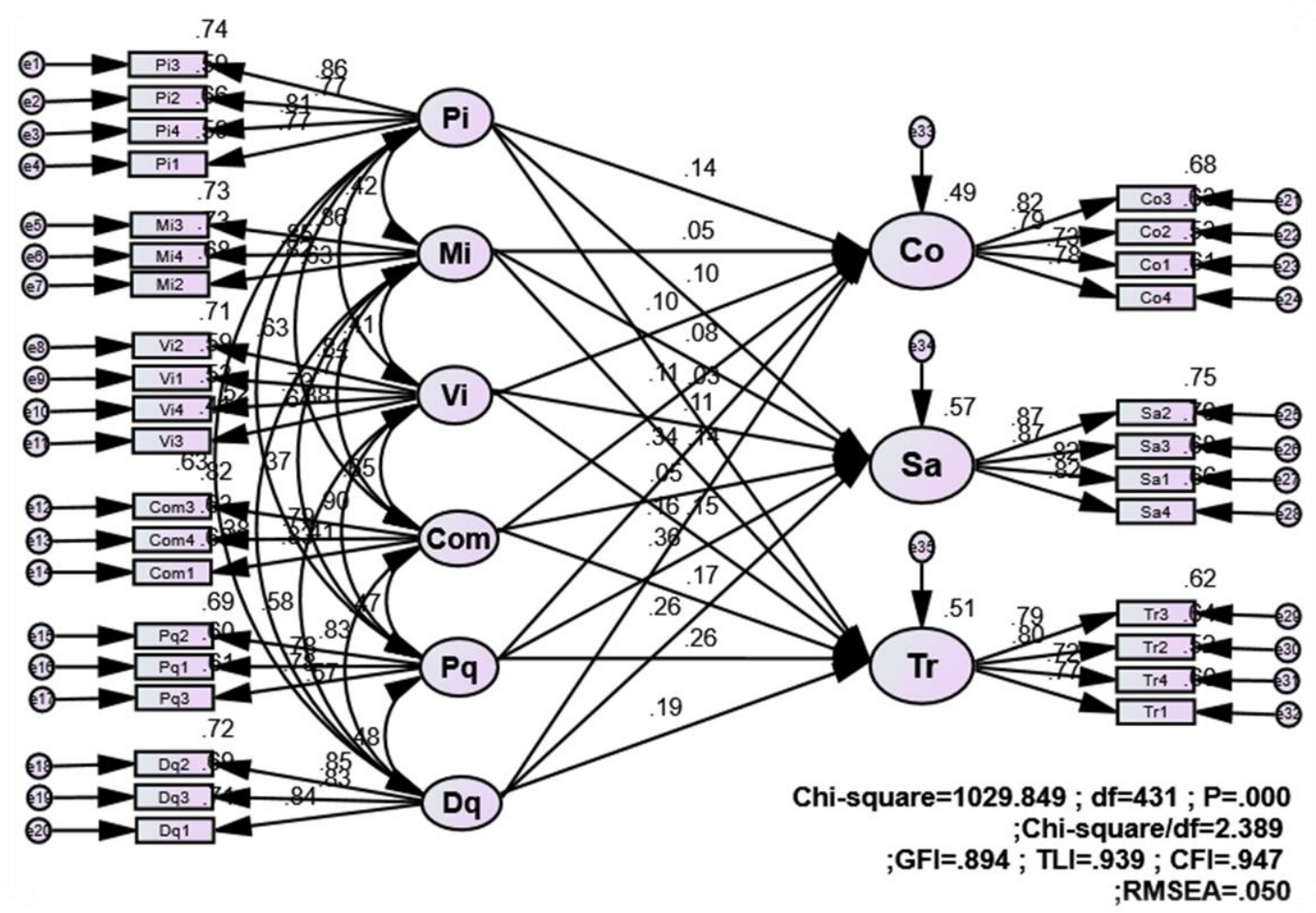

Figure 3. SEM results (standardized)

Testing hypotheses: The results of SEM testing relationships in the model are presented in Table 5. The Estimate of the concepts is positive, so the relationships impact positively. Of the 18 hypotheses of the model, there are 14 suitable and accepted hypotheses. In which, 11 hypotheses are accepted at the statistical significance level of $5 \%(\mathrm{p}<.05)$, including $\mathrm{H} 1 \mathrm{a}, \mathrm{H} 2 \mathrm{a}$, $\mathrm{H} 3 \mathrm{a}, \mathrm{H} 4 \mathrm{a}, \mathrm{H} 6 \mathrm{a}, \mathrm{H} 1 \mathrm{~b}, \mathrm{H} 2 \mathrm{~b}, \mathrm{H} 5 \mathrm{~b}, \mathrm{H} 1 \mathrm{c}, \mathrm{H} 2 \mathrm{c}$, and $\mathrm{H} 3 \mathrm{c}$ ), 3 The hypothesis is accepted at $10 \%$ statistical significance $(\mathrm{p}<.1$ ), including $\mathrm{H} 4 \mathrm{~b}, \mathrm{H} 5 \mathrm{c}$, and $\mathrm{H} 6 \mathrm{c}, 4$ inappropriate hypotheses (including $\mathrm{H} 5 \mathrm{a}, \mathrm{H} 3 \mathrm{~b}, \mathrm{H} 6 \mathrm{~b}$, and $\mathrm{H} 4 \mathrm{c}$ ). As follows:

Hypothesis H1a $(\lambda=0.263, \mathrm{p} \leq .001)$ is accepted at $5 \%$ statistical significance. This means that the higher the quality of the manufacturer, the more confident the distributor believes in the manufacturer. Hypothesis $\mathrm{H} 2 \mathrm{a}(\lambda=0.186, \mathrm{p} \leq .01)$ is accepted at a statistically significant level of $5 \%$. With the meaning that the manufacturer ensures the timely and accurate delivery of products and goods, the distributor is more confident in the manufacturer. Hypothesis $\mathrm{H} 3 \mathrm{a}(\lambda=0.143, \mathrm{p} \leq$ $.01)$ is accepted at 5\% statistical significance. It means that the manufacturer provides market information for full and appropriate distributor, the distributor will trust much on the publisher. Hypothesis $\mathrm{H} 4 \mathrm{a}(\lambda=0.171, \mathrm{p} \leq .01)$ is accepted at a statistically significant level of $5 \%$. In the sense that the manufacturer communicates well with the distributor, the distributor is more confident of the manufacturer. Hypothesis H5a $(\lambda=0.029, \mathrm{p}=.641>.1)$ is not accepted. This means that although the manufacturer interacts very well with the distributor, the two parties have not trusted each other. Hypothesis H6a $(\lambda=0.146, \mathrm{p} \leq .05)$ is accepted at a statistically significant level of $5 \%$. This means that the manufacturer regularly visits the distributor, the distributor will trust the manufacturer more. 


\section{Table 5}

Hypothesis testing results

\begin{tabular}{|c|c|c|c|c|c|c|}
\hline Hypothesis & \multicolumn{3}{|c|}{ Items } & $\lambda$ & $P$ - value & Results \\
\hline $\mathrm{H} 1 \mathrm{a}(+)$ & Product quality & $\rightarrow$ & Trust & .263 & $* * *$ & Accepted \\
\hline $\mathrm{H} 2 \mathrm{a}(+)$ & Delivery quality & $\rightarrow$ & Trust & .186 & .001 & Accepted \\
\hline $\mathrm{H} 3 \mathrm{a}(+)$ & Market information & $\rightarrow$ & Trust & .143 & .001 & Accepted \\
\hline $\mathrm{H} 4 \mathrm{a}(+)$ & Communication & $\rightarrow$ & Trust & .171 & .004 & Accepted \\
\hline $\mathrm{H} 5 \mathrm{a}(+)$ & Personal interaction & $\rightarrow$ & Trust & .029 & .641 & Rejected \\
\hline H6a (+) & Visit & $\rightarrow$ & Trust & .146 & .018 & Accepted \\
\hline $\mathrm{H} 1 \mathrm{~b}(+)$ & Product quality & $\rightarrow$ & Commitment & .339 & $* * *$ & Accepted \\
\hline $\mathrm{H} 2 \mathrm{~b}(+)$ & Delivery quality & $\rightarrow$ & Commitment & .156 & .006 & Accepted \\
\hline $\mathrm{H} 3 \mathrm{~b}(+)$ & Market information & $\rightarrow$ & Commitment & .049 & .268 & Rejected \\
\hline $\mathrm{H} 4 \mathrm{~b}(+)$ & Communication & $\rightarrow$ & Commitment & .106 & .076 & Accepted \\
\hline $\mathrm{H} 5 \mathrm{~b}(+)$ & Personal interaction & $\rightarrow$ & Commitment & .143 & .023 & Accepted \\
\hline $\mathrm{H6b}(+)$ & Visit & $\rightarrow$ & Commitment & .098 & .111 & Rejected \\
\hline $\mathrm{H} 1 \mathrm{c}(+)$ & Product quality & $\rightarrow$ & Satisfaction & .363 & $* * *$ & Accepted \\
\hline $\mathrm{H} 2 \mathrm{c}(+)$ & Delivery quality & $\rightarrow$ & Satisfaction & .255 & $* * *$ & Accepted \\
\hline $\mathrm{H} 3 \mathrm{c}(+)$ & Market information & $\rightarrow$ & Satisfaction & .084 & .037 & Accepted \\
\hline $\mathrm{H} 4 \mathrm{c}(+)$ & Communication & $\rightarrow$ & Satisfaction & .054 & .314 & Rejected \\
\hline $\mathrm{H} 5 \mathrm{c}(+)$ & Personal interaction & $\rightarrow$ & Satisfaction & .098 & .085 & Accepted \\
\hline $\mathrm{H} 6 \mathrm{c}(+)$ & Visit & $\rightarrow$ & Satisfaction & .107 & .056 & Accepted \\
\hline
\end{tabular}

Source: Author's synthesis

Hypothesis $\mathrm{H} 1 \mathrm{~b}(\lambda=0.339, \mathrm{p} \leq .001)$ is accepted at $5 \%$ statistical significance. It means that the higher the quality of the product, the better the distributor fulfills the commitments with the publisher. Hypothesis $\mathrm{H} 2 \mathrm{~b}(\lambda=0.156, \mathrm{p} \leq .01)$ is accepted at a statistically significant level of $5 \%$. With the meaning that the manufacturer ensures the timely and accurate delivery of products and goods, the distributor will perform well on the commitment to the manufacturer. Hypothesis $\mathrm{H} 3 \mathrm{~b}(\lambda=0.049, \mathrm{p}=.268>.1)$ is not accepted. It means that although the manufacturer provides an information center for the distributor fully, appropriately, and accurately, it is not sure that the distributor has well implemented its commitments to the publisher. Hypothesis $\mathrm{H} 4 \mathrm{~b}(\lambda=0.106, \mathrm{p}$ $\leq .1)$ is accepted at the $10 \%$ statistical significance level. With the meaning that the manufacturer communicates well with the distributor, the distributor is better at fulfilling its commitments with the publisher. Hypothesis $\operatorname{H} 5 \mathrm{~b}(\lambda=0.143, \mathrm{p} \leq .05)$ is accepted at a statistically significant level of $5 \%$. This means that the manufacturer interacts personally with the distributor, the better the distributor fulfills the commitments with the manufacturer. Hypothesis $\operatorname{H6b}(\lambda=0.098, p=.111>$ $.1)$ is not accepted. In the sense that although the manufacturer enhances the visit to the distributor, it is unlikely that the distributor has done well with its commitments to the manufacturer.

Hypothesis H1c $(\lambda=0.363, p \leq .001)$ is accepted at $5 \%$ statistical significance. It means that the higher the quality of the product, the better the distributor is satisfied with the 
manufacturer. Hypothesis $\mathrm{H} 2 \mathrm{c}(\lambda=0.255, \mathrm{p} \leq .001)$ is accepted at $5 \%$ statistical significance. With the meaning that the manufacturer ensures the delivery of products and goods for the distributor timely and accurately, the distributor is more satisfied with the manufacturer. Hypothesis $\mathrm{H} 3 \mathrm{c}(\lambda$ $=0.084, \mathrm{p} \leq .05)$ is accepted at a statistically significant level of $5 \%$. With the meaning that the manufacturer ensures the provision of the information center for the distributor timely and accurately, the distributor is more satisfied with the manufacturer. Hypothesis $\mathrm{H} 4 \mathrm{c}(\lambda=0.054, \mathrm{p}=$ $.314>.1)$ is not accepted. It means that although the manufacturer communicates well with the distributor, it is not sure that the distributor is satisfied with the manufacturer. Hypothesis $\mathrm{H} 5 \mathrm{c}$ ( $\lambda$ $=0.098, \mathrm{p} \leq .1)$ is accepted at a statistically significant $10 \%$ level. With the meaning that the manufacturer interacts personally with the distributor, the distributor is more satisfied with the manufacturer. Hypothesis H6c $(\lambda=0.107, \mathrm{p} \leq .1)$ is accepted at the $10 \%$ statistical significance level. This means that the manufacturer enhances the visit to the distributor, the more satisfied the distributor is with the manufacturer.

\subsection{Discussion on research results}

Discuss hypotheses compared to previous studies: The appropriate H1 (a,b,c) hypothesis should be accepted and similar to the H2 hypothesis: "Product quality has a positive effect on relationship value" in the research of T. D. Nguyen and T. T. M. Nguyen (2011, p. 319). Because relationship value is a precursor to RQ and is the behavior result of relationship marketing (Ulaga \& Eggert, 2006, p. 322), therefore, the product quality hypothesis has a positive effect on relationship value, which also means that product quality will have a positive impact on RQ.

The appropriate $\mathrm{H} 2(\mathrm{a}, \mathrm{b}, \mathrm{c})$ hypothesis should be accepted and similar to the H4 hypothesis: "Delivery performance has a positive effect on relationship value" in the study of T. D. Nguyen and T. T. M. Nguyen (2011, p. 320).

H3 Hypothesis: H3b is unsatisfactory so it is rejected. Appropriate H3a and H3c Hypothesis should be accepted and can be considered similar to the H1 hypothesis: Market information systems are positively related to business performance, in the research of Sabherwal and Chan (2001). Because business performance is the result of RQ (Alejandro, Souza, Boles, Ribeiro, \& Monteiro, 2011, p. 39), therefore, the market information system has a positive impact on business performance, which means that the market information system has a positive impact on RQ.

In addition, the study of T. D. Nguyen and T. T. M. Nguyen (2011, p. 320) has the H3 hypothesis: "Information support has a positive effect on relationship value".

Therefore, the $\mathrm{H} 3 \mathrm{a}$ and $\mathrm{H} 3 \mathrm{c}$ hypotheses of this study can be similar to the hypothesis of information support in the study of T. D. Nguyen and T. T. M. Nguyen (2011).

In the $\mathrm{H} 4$ hypothesis: $\mathrm{H} 4 \mathrm{a}$ and $\mathrm{H} 4 \mathrm{~b}$ are consistent and like the $\mathrm{H} 2$ hypothesis: "The greater the manufacturer's communication, the greater the economic satisfaction of the distributor" in the research of Rodríguez-del-Bosque et al. (2006, p. 668). The H4c hypothesis is similar to the H1 hypothesis: "The greater the manufacturer's communication, the greater the non-economic satisfaction of the distributor" in the research of Rodríguez-del-Bosque et al. (2006, p. 668). However, both hypotheses were rejected, the H4c hypothesis was excluded in this study and the H1 hypothesis was rejected in the study of Rodríguez-del-Bosque et al. (2006). Also, research of Tohidinia and Haghighi (2011, p. 244) has the H4 hypothesis: "There is a significant positive relationship between communication and relationship quality", but the results are excluded. Thus, the $\mathrm{H} 4 \mathrm{c}$ hypothesis is similar to the $\mathrm{H} 4$ hypothesis in the research of Tohidinia and Haghighi (2011). 
H5 Hypothesis: H5a failed and is rejected. H5b and H5c are consistent and like the H5 hypothesis: "Personal interaction has a positive effect on relationship value" in the study of T. D. Nguyen and T. T. M. Nguyen (2011, p. 320).

H6 Hypothesis: H6b is unsatisfactory so it is rejected. H6a Hypothesis: Visits have a positive impact on trust between manufacturers and distributors. H6c: Visits have a positive impact on satisfaction between producers and distributors. hese two hypotheses, after being appropriately tested and meet the requirements, the H6a and H6c hypotheses have not been found in previous studies. These are two new hypotheses discovered and supplemented in qualitative research of the thesis.

Discuss the contribution of research: Theoretically, this study has considered new contributions such as discovering the "visit" scale in qualitative research. Through reliability assessment, value evaluation, scale testing, suitable results, and acceptance. Because the visit is an equally important element in business strategy and tactics of the enterprise (Baldoquin de la Pena et al., 2014, p. 333). Researches in the past time just mentioned the need for visiting customers, considering visiting customers at the level of planning, visit schedules. There are no research documents on the scale of "visit" affecting RQ. On the other hand, the visit is one of the customs of Asian culture. Therefore, it can be considered that "visit" is a specific factor of the business culture of Asian culture. Additionally, the Theory of Planned Behavior can be used to explain the visit factor. Because, Theory of Planned Behavior is often used to predict intentions and behaviors in the areas of marketing and consumer behavior (Han, Hsu, \& Sheu, 2010; Lam \& Hsu, 2004). The manufacturer intends to visit the distributor to help both parties understand each other better. Distributors sense that the manufacturer cares about them, so they trust the manufacturer. The distributor's requirements for the manufacturer are met so they are satisfied with the manufacturer so that the commitments between the two parties can be fulfilled. Therefore, visit is a new factor affecting the components of quality of the manufacturer-distributor relationship.

The research results of the thesis have the theoretical contributions inherited from the previous studies as follows:

Firstly, research results have developed a market information scale based on the market information system factor of Sabherwal and Chan (2001). Through reliability assessment, value evaluation, scale testing, suitable results, and acceptance. Therefore, market information is an inherited scale and a factor ffecting the quality of the manufacturer-distributor relationship in the context of the plastic industry in Vietnam.

Second, the three scales of product quality, delivery quality and personal interaction are derived from researches of relationship value (T. D. Nguyen \& T. T. M. Nguyen, 2011) were tested in the research model of manufacturer-distributor relationship in plastic industry in Vietnam, the results are consistent and accepted.

According to T. D. Nguyen and T. T. M. Nguyen (2011, p. 393), product quality is an important factor that creates value for a business relationship. In the manufacturer-distributor relationship, the distributor maintains a relationship with the manufacturer to always have high quality and reliable products (Ulaga, 2003). If the manufacturer provides the distributor with highquality products, it will help the distributor reduce the costs of resolving the customer's complaints, thus increasing the value of the relationship (Cannon \& Homburg, 2001). Delivery quality is also a potential factor to increase the value of the manufacturer-distributor relationship (T. D. Nguyen and T. T. M. Nguyen, 2011, p. 395). Manufacturers deliver goods in the right quantities, specifications, and types will help distributors save time and unnecessary procedures, contributing 
to increasing relationship value between manufacturers - distributors (Ulaga, 2003). In addition, improving the personal interaction between manufacturers - distributors will benefit both parties because they are easier to communicate with each other and increase mutual understanding in a relationship, make it more convenient to solve business problems (Cater \& Cater, 2010; Ulaga, 2003). Therefore, personal interaction impacts the same direction on relationship value (T. D. Nguyen \& T. T. M. Nguyen, 2011, p. 396).

The above arguments show that product quality, delivery quality and personal interaction are the three factors that impact the same direction on the relationship value, increasing the value of the relationship between manufacturer and distributor. In this study, the above three factors are considered to be inherited from previous studies, and positively impact the components of RQ. Contribute to prove the argument of Ulaga \& Eggert (2006, p. 322): "relationship value" is the precursor of "relationship quality".

\section{Conclusions, meanings, and limitations}

The relationship quality between manufacturers and distributors in the plastic industry in Vietnam is a multidimensional concept, consisting of three components: trust, commitment, and satisfaction. The six factors that influence the components of relationship quality are product quality, delivery quality, market information, communication, personal interaction, and visits. In particular, visit is a newly discovered factor. This is a unique factor of the business culture of Asian culture. The market information factor is a scale inherited from the research of Sabherwal and Chan (2001) and is a factor affecting the quality of the manufacturer-distributor relationship in the context of the plastics industry in Vietnam. The three factors product quality, delivery quality and personal interaction are considered inherited from previous studies, and impact the same direction on the components of RQ. Contribute to demonstrate relationship value is the precursor to relationship quality.

To improve the quality of relationships with distributors, manufacturers, need to care about building trust, fulfilling commitments, and meeting the requirements of distributors. Manufacturers need to pay attention to product quality, enhance technical improvements to enhance product quality. Next, manufacturers must pay attention to the delivery, providing enough market information for distributors. In addition, the manufacturer needs to improve communication, personal interaction, and frequent visits to distributors.

This research considers the composition of RQ, factors affecting the composition of quality relationships between manufacturers and distributors in Ho Chi Minh City, the western provinces and some southeast provinces and from the perspective of the distributor, other markets (such as the Central and the Northern) and interviews with other subjects such as manufacturers, suppliers of raw materials, etc... will bring different results in terms of ingredients of RQ and factors that influence the composition of RQ. This issue opens the next research direction.

\section{References}

Alejandro, T. B., Souza, D. V., Boles, J. S., Ribeiro, A. H. P., \& Monteiro, P. R. R. (2011). The outcome of company and account manager relationship quality on loyalty, relationship value and performance. Industrial Marketing Management, 40(1), 36-43. doi:10.1016/j.indmarman.2010.09.008

Anderson, J., \& Narus, J. A. (1990). A model of distributor firm and manufacturer firm working partnerships. Journal of Marketing, 54(1), 42-58. doi:10.2307/1252172 
Athanasopoulou, P. (2008). Antecedents and consequences of relationship quality in athletic services. Managing Service Quality, 18(5), 479-495. doi:10.1108/09604520810898848

Athanasopoulou, P. (2009). Relationship quality: A critical literature review and researchagenda. European Journal of Marketing, 43(5/6), 583-610. doi:10.1108/03090560910946945

Athanasopoulou, P., Kalogeropoulou, D., \& Douvis, J. (2013). Relationship quality in sports: A study in football teams and fitness centres. Sport, Business and Management: An International Journal, 3(2), 100-117. doi:10.1108/20426781311325041

Aurier, P., \& Séré de Lanauze, G. (2011). Impacts of in-store manufacturer brand expression on perceived value, relationship quality and attitudinal loyalty. International Journal of Retail \& Distribution Management, 39(11), 810-835. doi:10.1108/09590551111177945

Bagozzi, R. P., \& Yi, Y. (1988). On the evaluation of structural equation models. Journal of the Academy of Marketing Science, 16(1), 74-91. doi:10.1007/bf02723327

Baker, T. L., Simpson, P. M., \& Siguaw, J. A. (1999). The impact of suppliers' perceptions of reseller market orientation on key relationship constructs. Journal of the Academy of Marketing Science, 27(1), 50-57. doi:10.1177/0092070399271004

Baldoquin de la Pena, M. G., Escalera Farinas, A., \& Linfati, R. (2014). A model and solution method for solving the real-world and complex problem of scheduling visits to customers. Journal of Applied Research and Technology, 12(3), 333-342. doi:10.1016/S16656423(14)71616-5

Bejou, D., Wray, B., \& Ingram, T. N. (1996). Determinants of relationship quality: An artificialneural network analysis. Journal of Business Research, 36(2), 137-143. doi:10.1016/0148-2963(95)00100-X

Berry, L. L. (1995). Relationship marketing of services-growing interest, emerging perspectives. Journal of the Academy of Marketing Science, 23(4), 236-245. doi:10.1177/009207039502300402

Bojei, J., \& Alwie, A. (2010). The influence of relationship quality on loyalty in service sector. International Journal of Economics and Management, 4(1), 81-100.

Bove, L. L., \& Johnson, L. W. (2001). Customer relationships with service personnel: Do we measure closeness, quality or strength? Journal of Business Research, 54(3), 189-197. doi:10.1016/S0148-2963(00)00122-3

Brick, M. (2011). The future of survey sampling. Public Opinion Quarterly (Special Issue), 75(5), 872-888. doi:10.1093/poq/nfr045

Cannon, J. P., \& Homburg, C. (2001). Buyer-supplier relationships and customer firm costs. Journal of Marketing, 65(1), 29-43. doi:10.1509/jmkg.65.1.29.18136

Cater, T. \& Cater, B. (2010). Product and relationship quality influence on customer commitment and loyalty in B2B manufacturing relationships. Industrial Marketing Management, 39(8), 1321-1333. doi:10.1016/j.indmarman.2010.02.006

Chen, Y. S., Su, H. C., \& Ro, Y. K. (2017). The co-evolution of supplier relationship quality and product quality in the U.S. auto industry: A cultural perspective. International Journal of Production Economics, 184(C), 245-255. doi:10.1016/j.ijpe.2016.12.020

Clark, M. N., Adjei, M. T., \& Yancey, D. N. (2009). The impact of service fairness perceptions on relationship quality. Services Marketing Quarterly, 30(3), 287-302. doi:10.1080/15332960902993577 
Collins, C., \& Clark, K. (2003). Strategic human resource practices, top management team social networks, and firm performance: The role of human resource practices in creating organizational competitive advantage. Academy of Management Journal, 46(6), 740-751. doi: $10.5465 / 30040665$

Crosby, L. A., Evans, K. R., \& Cowless, D. (1990). Relationship quality in services selling: An interpersonal influence perspective. Journal of Marketing, 54(3), 68-81. doi: $10.2307 / 1251817$

Cumming, R. (1990). Is probability sampling always better? A comparison of results from a quota and probability sample survey. Community Health Studies, 14(2), 132-137. doi:10.1111/j.1753-6405.1990.tb00033.x

Doney, P. M., \& Cannon, J. P. (1997). An examination of the nature of trust in buyer-seller relationships. Journal of Marketing, 61(2), 35-51. doi:10.1177/002224299706100203

Dwyer, F. R., Schurr, P. H., \& Oh, S. (1987). Developing buyer-seller relationships. Journal of Marketing, 51(3), 11-27. doi:10.1177/002224298705100202

Ebrahimi, M., Haghighinasab, M., Sattari, B., \& Roghanian, P. (2013). The effect of channel function performance on relationship quality with organizational buyers: A case study in iranian food distribution company. International Journal of Fundamental Psychology and Social Sciences, 3(3), 42-47. doi:10.14331/ijfpss.2013.330033

Forslund, H., Jonsson, P., \& Mattsson, S. (2009). Order-to-delivery performance in delivery scheduling environments. International Journal of Productivity and Performance Management, 58(1), 41-53. doi:10.1108/17410400910921074

Gerbing, W. D., \& Anderson, J. C. (1988). An update paradigm for scale development incorporating unidimensionality and its assessments. Journal of Marketing Research, 25(2), 186-192. doi:10.1177/002224378802500207

Geyskens, I., Steenkamp, J.-B. E. M., \& Kumar, N. (1999). A meta-analysis of satisfaction in marketing channel relationships. Journal of Marketing Research, 36(2), 223-238. doi: $10.2307 / 3152095$

Grönroos, C., Storbacka, K., \& Strandvik, T. (1994). Managing customer relationships for profit: The dynamics of relationship quality. International Journal of Service Industry Management, 5(5), 21-38. doi:10.1108/09564239410074358

Hair, J. F., Black, W. C., Babin B. J., \& Anderson, R. E. (2010). Multivariate data analysis (7th ed.). London, UK: Person Prentice Hall.

Han, H., Hsu, L., \& Sheu, C. (2010). Application of the theory of planned behavior to green hotel choice: Testing the effect of environmental friendly activities. Tourism Management, 31(3), 325-334. doi:10.1016/j.tourman.2009.03.013

Harmancioglu, N., Grinstein A., \& Goldman, A. (2010). Innovation and performance outcomes of market information collection efforts: The role of top management team involvement. International Journal of Research in Marketing, 27(1), 33-43. doi:10.1016/j.ijresmar.2009.09.005

Hibbard, J. D., Kumar, N., \& Stern, L.W. (2001). Examining the impact of destructive acts in marketing channel relationships. Journal of Marketing Research, 38(1), 45-61. doi:10.1509/jmkr.38.1.45.18831 
Hopkinson, G. C., \& Hogarth-Scott, S. (1999). Franchise relationship quality: Micro-economic

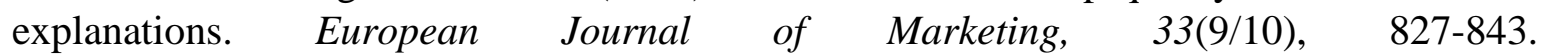
doi:10.1108/03090569910285751

Huang, Q., Davison, R. M., \& Liu, H. (2014). An exploratory study of buyers' participation intentions in reputation systems: The relationship quality perspective. Information \& Management, 51(8), 952-963. doi:10.1016/j.im.2014.09.003

Izogo, E. E., Reza, A., Ogba, I.-E., \& Oraedu, C. (2017). Determinants of relationship quality and customer loyalty in retail banking: Evidence from Nigeria. African Journal of Economic and Management Studies, 8(2), 186-204. doi:10.1108/AJEMS-01-2016-0011

Jap, S. D., \& Ganesan, S. (2000). Control mechanisms and the relationship life cycle: Implications for safeguarding specific investments and developing commitment. Journal of Marketing Research, 37(2), 227-245. doi:10.1509/jmkr.37.2.227.18735

Japutra, A., Keni, K., \& Nguyen, B. (2015). The impact of brand logo identification and brand logo benefit on Indonesian consumers' relationship quality. Asia-Pacific Journal of Business Administration, 7(3), 237-252. doi:10.1108/APJBA-10-2014-0124

Jarvelin, A., \& Lehtinen, U. (1996). Relationship quality in business-to-business service context. In B. B. Edvardsson, S.W. Johnston, \& E. E. Scheuing (Eds.), QUIS 5 advancing service quality: A global perspective (pp. 243-254). Lethbridge, Canada: Warwick Printing.

John, M., \& Christopher, W. (1999). Interfirm relationships and informal credit in Vietnam. The Quarterly Journal of Economics, 114(4), 1285-1320.

Johnson, J. L., Sakano, T., Cote, J. A., \& Onzo, N. (1993). The exercise of interfirm power and its repercussions in US-Japanese channel relationships. Journal of Marketing, 57(2), 1-10. doi: $10.2307 / 1252023$

Kumar, N., Scheer, L. K., \& Steenkamp, J. -B. E. M. (1995). The effects of perceived interdependence on dealer attitudes. Journal of Marketing Research, 32(3), 348-356. doi:10.1177/002224379503200309

Lagace, R. R., Dahlstrom, R., \& Gassenheimer, J. B. (1991). The relevance of ethical salesperson behavior on relationship quality: The pharmaceutical industry. Journal of Personal Selling and Sales Management, 11(4), 39-47. doi:10.1080/08853134.1991.10753888

Lam, T., \& Hsu, C. H. C. (2004). Theory of planned behavior: Potential travelers from China. Journal of Hospitality \& Tourism Research, 28(4), 463-482. doi:10.1177/1096348004267515

Leonidou, L. C., Barnes, B. R., \& Talias, M. A. (2006). Exporter-importer relationship quality: The inhibiting role of uncertainty, distance, and conflict. Industrial Marketing Management, 35(5), 576-588. doi:10.1016/j.indmarman.2005.06.012

Lindskold, S. (1978). Trust development, the GRIT proposal, and the effects of conciliatory acts on conflict and cooperation. Psychological Bulletin, 85(4), 772-793. doi:10.1037/00332909.85.4.772

Loureiro, S. M. C., \& Cunha, N. (2017). Relationship quality between portuguese wine producers and chinese distributors insight and recommendations. The Wine Value Chain in China, 9(5), 163-186. doi:10.1016/B978-0-08-100754-9.00011-8 
Madupalli, R., Pannirselvam, G., \& Williams, C. (2014). Quality of business-to-business relationships: Impact of customer - supplier differences. Academy of Marketing Studies Journal, 18(2), 149-167.

Mainela, T., \& Ulkuniemi, P. (2013). Personal interaction and customer relationship management in project business. Journal of Business and Industrial Marketing, 28(2), 103-110. doi:10.1108/08858621311295245

Moliner, J.-R. S., Moliner, M. A., \& Sanchez-Garcia, J. (2013). To business: A cross-cultural perspective from universities. Marketing Intelligence \& Planning, 31(3), 196-215. doi:10.1108/02634501311324573

Moorman, C., Zaltman, G., \& Deshpande, R. (1993). Relationships between providers and users of market research: The dynamics of trust within and between organizations. Journal of Marketing Research, 29(3), 314-329. doi:10.2307/3172742

Morgan, R. M., \& Hunt, S. D. (1994). The commitment-trust theory of relationship marketing. Journal of Marketing, 58(3), 20-38. doi:10.2307/1252308

Naoui, F. B., \& Zaiem, I. (2010). The impact of relationship quality on client's loyalty: An application in the parapharmaceutical industry. International Journal of Pharmaceutical and Healthcare Marketing, 4(2), 137-156. doi:10.1108/17506121011059759

Narus, J. A., \& Anderson, J. C. (1987). Distributor contributions to partnerships with manufacturers. Business Horizons, 30(5), 34-42. doi:10.1016/0007-6813(87)90077-2

Naude, P., \& Buttle, F. (2000). Assessing relationship quality. Industrial Marketing Management, 29(4), 351-361. doi:10.1016/S0019-8501(00)00112-7

Ndubisi, N. O. (2006). A structural equation modeling of the antecedents of relationship quality in the Malaysia banking sector. Journal of Financial Services Marketing, 11, 131-141. doi:10.1057/palgrave.fsm.4760033

Nguyen, T. D., \& Nguyen, T. T. M. (2011). Enhancing relationships value between manufacturers and distributors through personal interaction: Evidence from Vietnamese. Journal of Management Development, 30(4), 316-328. doi:10.1108/02621711111126800

Nguyen, T. T. M., \& Nguyen, T. D. (2010). Learning to build quality business relationships in export markets: Evidence from Vietnamese exporters. Asia Pacific Business Review, 16(1/2), 203-220. doi:10.1080/13602380802280009

Nguyen, T. T. M., \& Nguyen, T. D. (2014). Enhancing business relationship quality through cultural sensitization. Journal of Relationship Marketing, 13(1), 70-87. doi:10.1080/15332667.2014.882177

Nishio, S., \& Kishino, F. (1999). Advanced multimedia content processing: First international conference, AMCP'98, Osaka, Japan, November 9-11, 1998, Proceedings. Heidelberg, Germany: Springer-Verlag.

Parasuraman, A., Zeithaml, V. A., \& Berry, L. L. (1985). A conceptual model of service quality and its implications for future research. Journal of Marketing, 49(4), 41-50. doi:10.2307/1251430

Pepur, M., Mihanovic, Z., \& Pepur, S. (2013). Analysis of the effect of perceived service quality to the relationship quality on the business-to-business market. Management, 18(2), 97-109. 
Rauyruen, P., \& Miller, K. E. (2007). Relationship quality as a predictor of B2B customer loyalty. Journal of Business Research, 60(1), 21-31. doi:10.1016/j.jbusres.2005.11.006

Rodríguez-del-Bosque, I., Agudo, J. C., \& Gutierrez, H. S. M. (2006). Determinants of economic and social satisfaction in manufacturer-distributor relationships. Industrial Marketing Management, 35(6), 666-675. doi:10.1016/j.indmarman.2005.05.006

Sabherwal, R., \& Chan, Y. (2001). Alignment between business and IS strategies: A study of prospectors, analyzers, and defenders. Information Systems Research, 12(1), 11-33. doi:10.1287/isre.12.1.11.9714

Sarstedt, M., Bengart, P., Shaltoni, A. M., \& Lehmann, S. (2017). The use of sampling methods in advertising research: A gap between theory and practice. International Journal of Advertising, 37(4), 650-663. doi:10.1080/02650487.2017.1348329

Shpetim, C. (2012). Exploring factor affecting trust and relationship quality in a supply chain context. Journal of Business Studies Quarterly, 4(1), 74-90.

Skarmeas, D., Katsikeas, C. S., Spyropoulou, S., \& Sangari, E. S. (2008). Market and supplier characteristics driving distributor relationship quality in international marketing channels of industrial products. Industrial Marketing Management, 37(1), 23-36. doi:10.1016/j.indmarman.2007.04.004

Smith, J. B. (1998). Buyer-seller relationships: Bonds, relationship management, and sex-type. Canadian Journal of Administrative Sciences, 15(1), 76-92. doi:10.1111/j.19364490.1998.tb00153.x

Song, M., \& Zhao, Y. (2004). A neural network for predicting manufacturers' perceived cooperation with distributors in the new product development process. Journal of Businessto-Business Marketing, 11(3), 53-78. doi:10.1300/J033v11n03_03

Tohidinia, Z., \& Haghighi, M. (2011). Predictors and outcomes of relationship quality: A guide for customer-oriented strategies. Business Strategy Series, 12(5), 242-256. doi:10.1108/17515631111166889

Ulaga, W. (2003). Capturing value creation in business relationships: A customer perspective. Industrial Marketing Management, 32(8), 677-693. doi:10.1016/j.indmarman.2003.06.008

Ulaga, W. \& Eggert, A. (2006). Relationship value and relationship quality: Broadening the nomological network of business-to-business relationships. European Journal of Marketing, 40(3/4), 311-327. doi:10.1108/03090560610648075

Ural, T. (2009). The effects of relationship quality on export performance: A classification of small andmedium-sized turkish exporting firms operating in single export-market ventures. European Journal of Marketing, 43(1/2), 139-168. doi:10.1108/03090560910923274

Van Bruggen, G. H., Kacker, M., \& Nieuwlaat, C. (2005). The impact of channel function performance on buyer-seller relationships in marketing channels. International Journal of Research in Marketing, 22(2), 141-158. doi:10.1016/j.ijresmar.2004.06.004

Velez, M. L., Sanchez, J. M., Florez, R., \& Alvarez-Dardet, C. (2015). How control system information characteristics affect exporter-intermediary relationship quality. International Business Review, 24(5), 812-824. doi:10.1016/j.ibusrev.2015.02.008 
Walter, A., Muller, T., Helfert, G., \& Ritter, T. (2003). Functions of industrial supplier relationships and their impact on relationship quality. Industrial Marketing Management, 32(2), 159-169. doi:10.1016/S0019-8501(02)00230-4

Woo, K., \& Ennew, C. T. (2004). Business-to-business relationship quality: An IMP interactionbased conceptualization and measurement. European Journal of Marketing, 38(9/10), 12521271. doi:10.1108/03090560410548960

Wray, B., Palmer, A., \& Bejou, D. (1994). Using neural network analysis to evaluate buyer-seller relationships. European Journal of Marketing, 28(10), 32-48. doi:10.1108/03090569410075777

Yang, K., \& Banamah, A. (2014). Quota sampling as an alternative to probability sampling? An experimental study. Sociological Research Online, 19(1), 1-11. doi:10.5153/sro.3199 